\title{
Hatching response to temperature along a latitudinal gradient by the fairy shrimp Branchinecta lindahli (Crustacea; Branchiopoda; Anostraca) in culture conditions
}

\author{
D. Christopher ROGERS ${ }^{1,2^{*}}$
}

${ }^{1}$ Kansas Biological Survey and the Biodiversity Institute, Kansas University, Higuchi Hall, 2101 Constant Avenue, Lawrence, KS 66047-3759 USA; ${ }^{2}$ University of New England, Armidale, 2351, Australia

*Corresponding author: branchiopod@gmail.com

\begin{abstract}
Branchinecta lindahli is a broadly distributed fairy shrimp, reported from a range of temporary wetland habitat types in arid western North America. This species' eggs hatch after the habitat dries, refills from seasonal rain, and receives a strong cold shock during the winter low temperatures. I studied phenotypic variation in temperature responses in cultures collected from four populations across $8^{\circ}$ of latitude with low average temperatures ranging from -8 to $8^{\circ} \mathrm{C}$. Time to maturation, mature body size and first clutch size decreased, as temperature increased, with only minor body size variability at mortality, regardless of culture origin. No variation in individual egg size was observed, demonstrating that body size is sacrificed to produce at least a few normal eggs during unfavourable years. Latitudinal variation in hatching temperature demonstrated a pattern of adaptive significance, with some overlap between regional temperature hatching cues. Phenotypic hatching temperature and growth rate responses may cause genetic segregation, selecting one cohort for warmer, dryer years and one cohort for cooler, wetter years. Drier year selected cohorts can exploit habitats that have shorter hydroperiods even in wet years. This may lead to population specialisation and speciation by adapting to more extreme habitats.
\end{abstract}

Key words: Thermal gradient, population biology, cohorts, dispersal, evolution, adaptation.

Received: June 2014. Accepted: July 2014.

\section{INTRODUCTION}

The fairy shrimp Branchinecta lindahli Packard, 1883 is a widespread North American species known from Canada (Alberta), USA (Arizona, California, Colorado, Iowa, Kansas, Montana, Nebraska, Nevada, New Mexico, North Dakota, Oklahoma, Oregon, Washington, Wyoming), and Mexico (Baja California, Baja California Sur) (Lynch, 1964; Hartland-Rowe, 1965; Belk, 1975, 1977a, 1977b, 1983; Belk and Brtek, 1995; Eng et al., 1990; Eriksen and Belk, 1999; Maeda-Martinez et al., 2002). This broadly distributed species is recorded from a range of endorheic temporary wetland habitat types from dryland regions, including: alkaline vernal pools, prairie potholes, and slightly saline pools and playas (Hartland-Rowe, 1965; Horne, 1967, 1971; Belk, 1977b, 1983; Eng et al., 1990; Gonzales et al., 1996; Eriksen and Belk, 1999; Maeda-Martinez et al., 2002). Horne (1967, 1971 ) reported that $B$. lindahli is remarkably tolerant of a wide range of dissolved salts types and concentrations. This species is known from turbid and clear water habitats (Eng et al., 1990). It is commonly encountered in artificial habitats, such as roadside ditches and railroad bed toe drains (and has been recorded co-occurring in the same habitats with fifteen other fairy shrimp species in five other genera) and the adults typically swim in temporary wetlands that hold water November to April (Lynch,
1964; Hartland-Rowe, 1965; Belk, 1977b, 1983; Eng et al., 1990; Eriksen and Belk, 1999; Maeda-Martinez et al., 2002). Simovich and Fugate (1992) reported that B. lindahli can reach the adult stage in as little as eight days.

Like most Branchinecta species, B. lindahli is a winter/spring species, with its eggs hatching after a strong cold shock (Belk, 1973, 1977a; Belk and Nelson, 1995), and like most fairy shrimp, only hatches after subsequent drying and rehydration (Hall, 1959; Prophet, 1963a; Belk, 1973, 1977a, 1977b; Brendonck, 1996; Eriksen and Belk, 1999). Furthermore, the eggs are inhibited from hatching at higher temperatures, regardless of length of hydration (Belk, 1973; Belk and Nelson, 1995). Although some anostracans produce eggs requiring diapause as well as eggs that do not (summarised in Brendonck et al., 1993; Brendonck, 1996), this has not been observed in B. lindahli.

Hatching timing is paramount to temporary wetland crustacean survival; synchronised hatching, growth and reproduction must coincide with the habitat hydroperiod. Therefore, hatching timing selection pressure must be strong, especially since only a fraction of each egg clutch hatches with each inundation (Belk and Cole, 1975; Brendonck et al., 2000). It is logical to assume that temperature is an important hatching cue, since lower temperatures would indicate that the likelihood of the endorheic habitat desiccating is relatively low. By using a single, widespread, generalist species, most aspects of basic genetics 
and life history can be held constant while hatching and climate variation relationships emerge. An anostracan species with broad water chemistry requirements so widely distributed across 8 degrees of latitude makes an ideal subject to study phenotypic variation in hatching temperature responses. This study's purpose is to document variation in temperature response from $B$. lindahli populations across a wide latitudinal and altitudinal range, as regards hatching, time to first clutch, body size at first clutch and first clutch size, while holding water chemistry conditions, habitat volume, photoperiod, and food nutritive quality constant, to determine if there is specific adaptation to local temperature ranges.

\section{METHODS}

Branchinecta lindahli eggs were field collected from four widely separated sites known to support $B$. lindahli. Adult shrimp were identified morphologically following the appropriate literature (Lynch, 1964; Belk, 1975; Eriksen and Belk, 1999). In 2011, all four populations were verified to be the same taxon using molecular analyses using both nuclear DNA and the mitochondrial cytochrome C oxidase I gene. Egg laden soil was selected from these specific sites to obtain material from a wide variety in latitudinal localities (from south to north) and a wide range of elevations, but all from habitats of similar depth and area:

USA: CALIFORNIA: Lassen County: Madeline Plains; pool dimensions: $210 \mathrm{~m}^{2}, 10 \mathrm{~cm}$ deep; 23 March 1998, D.C. Rogers. Riverside County: Skunk Hollow, soil collected in 1988 by C. Eriksen; pool dimensions: $198 \mathrm{~m}^{2}$, $13 \mathrm{~cm}$ deep; D.C. Rogers. San Luis Obispo County: puddles along rail-road tracks in Santa Margarita; pool dimensions: $204 \mathrm{~m}^{2}, 15 \mathrm{~cm}$ deep; 13 February 1999, D.C. Rogers, E.C. Rogers, H.L. Rogers, C.L. Rogers. Yolo County: Rail-road toe drain on west side of tracks along K Street, north of Eighth Street, Davis; pool dimensions: $219 \mathrm{~m}^{2}, 6 \mathrm{~cm}$ deep; 29 July 2009; D.C. Rogers.

While this species does occur over a greater latitudinal range than these four sites in California, the localities where it occurs in Washington and Oregon do not suffer colder temperatures or longer cold spells than does the site in Lassen County, California. Conversely, populations in Mexico may experience warmer temperatures than occur in Riverside, California. However, it is problematical, expensive, and requires a variety of permits from both nations to transport soil containing live organisms across United States borders, particularly where those soil samples may have been in contact with livestock.

Several soil samples from each site of $500 \mathrm{~mL}$ per sample were prepared for examination in the laboratory by dissolving the clumps of soil in water and sieving the material through 300 and $150 \mathrm{~mm}$ pore size screens. The small size of these screens ensures that shrimp eggs
( $250 \mathrm{~mm}$ in diameter) will be retained. The portion of each sample retained in the screens was dissolved in a saturated sodium chloride brine solution to separate the organic material from the inorganic material. The organic fraction was then spread on a petri dish of known surface area, allowed to dry, and examined under a microscope for shrimp eggs. All dry eggs were removed from the filtered debris left over from the soil sieving. Four active cultures were prepared from each of these four sites and were maintained in the laboratory annually or semi annually (each or every other year rehydrated, the eggs hatched and reared to reproducing adults, and dried out) from the time they were collected to the present. Cultures for this experiment were started in 2012. All cultures were maintained in a Thermo Scientific Precision ${ }^{\odot}$ (Waltham, MA, USA) incubator at $\pm 1^{\circ}$ of the designated air temperatures (see below), with automatic timers on the lights. For each of the four collection sites, four separate replicate cultures were established. Each replicate culture was started from eggs harvested from adults reared from the original culture, not from eggs in the culture itself. Twenty egg bearing females were removed from the original culture, placed in isolation in glass culture dishes, and when their eggs were shed, those eggs were used to start a replicate culture from the original culture's origin. These cultures were run through two generations. After two generations, 100 eggs were isolated from twenty egg bearing females per each culture (not the substrate) for the present experiment. Each female was used for only one culture replicate. This method was used to produce four cultures from each site and four replicates of each culture. Each replicate culture for this experiment contained 100 eggs randomly collected from twenty females not used for other culture replicates. Thus, there was no potential for siblings to be in different cultures or culture replicates.

For each collection site, one culture was submitted to the same low and high average annual winter and spring (January to April) time air temperature conditions as that culture's original collection site (origin) (Tab. 1). One of each of the remaining three cultures were submitted to the same (January to April) low and high average annual air temperature conditions (averaged over 25 years: 19872012) that the other three collection sites would naturally experience (National Oceanic and Atmospheric Administration databases, http://www.noaa.gov/; Weather Underground, www.wunderground.com/). This was replicated four times, for a grand total of 64 cultures of 100 eggs each. Each culture was run in the same incubator, but run independently and separately from all other cultures: no two cultures were run simultaneously in the incubator for this study. Air temperatures were used instead of water temperature as water temperature data over so great a period was not generally available (if at all) from the four sites. During the experiments, the culture water only varied from the air 
temperature by two degrees or less. As the temperature range for each of these localities was several times greater than this variation (National Oceanic and Atmospheric Administration databases, http://www.noaa.gov/) this variability was deemed negligible.

Sixteen litres of distilled tap water and deionized water with a final conductivity of $30 \mu \mathrm{S}$ (microsiemens) was added to each culture at the beginning of the incubation. No additional water was provided for the duration of each individual culture. All cultures were provided with the same photoperiod of $12 \mathrm{~h}$ of light and $12 \mathrm{~h}$ of darkness under F40 broad spectrum fluorescent grow lights. One set of four replicates from each of the four collection sites was incubated for $120 \mathrm{~h}$ (five days) at the annual average lowest air January temperature for each of the four collection localities (Tab. 1). The five day incubation time was selected, as this was the average length of time low temperatures were sustained across the four localities during the last ten years. Annual average lowest air temperature data was gathered from the National Oceanic and Atmospheric Administration databases (http://www.noaa.gov/) and from The Weather Underground (http://www.wunderground.com/). After the five day incubation period, the cultures were brought to $15^{\circ} \mathrm{C}$ over a 48 -h period. Each sample was hydrated and incubated once. All newly hatched shrimp were collected in the dark by attracting them to one corner of the culture container with a small light, and captured with a pipette into a small petri dish with water from the culture. The nauplii were counted and returned to culture. All shrimp were fed on equal amounts of the same mixture of brewer's yeast and commercial fish flake food: $5.0 \mathrm{~mL}$ of the mixture was suspended in $10 \mathrm{~mL}$ distilled tap water, and added to culture every day. Upon reaching $15^{\circ} \mathrm{C}$, each culture was then raised to the annual average highest April springtime air temperature for each of the four collection localities over a 48-h period (Tab. 1), and maintained at this temperature until the culture dried out. The 48-h period for temperature increase was selected, as all sites had experienced temper- ature increases in this short of a period at some point in the last ten years (http://www.noaa.gov/). The number of days to first egg clutch in each replicate was recorded. Only the first female with a clutch in each replicate was sacrificed in order to count the number of eggs. This clutch was selected, as not all cultures had more than one clutch. The period from initial inundation to highest temperature was 216 $\mathrm{h}$ (nine days). When all females in a given replicate had egg clutches, all females were measured form the anterior margin of the head to the posterior margin of the telson (not including cercopods) and returned to their cultures.

A maximum of forty eggs from each sacrificed female had their diameter measured. If forty or fewer eggs were present in the clutch, then all eggs were measured. All fully formed eggs were counted. A total of 1186 eggs were counted and 507 were measured using a stage micrometer. Eggs were occasionally found that were less than half the size of normal eggs. These eggs were dissected and found to be solid egg shell, with no embryo inside at all. As these were not true eggs they were excluded from the study. Measurements of adults were made from the anterior margin of the head to the posterior medial margin of the telson. Adults and eggs were measured using a stage micrometer. Simple statistics (means and variance) were calculated from the data. ANOVA/MANOVA was not possible due to violation of the assumption of equivariance. Any results of statistical analyses would not be particularly robust do to the small size and number of the zeroes in the data set.

\section{RESULTS}

The specific results are presented in Tab. 2 . The per cent hatch of each culture was highest in the origin condition cultures. The Riverside County culture replicates subjected to Lassen County culture origin low temperature conditions died (southernmost cultures at northern most culture low temperatures). Additional repeated incubations of these cul-

Tab. 1. Branchinecta lindahli culture collection sites (from south to north) and average annual winter/spring temperatures for each site averaged over 25 years.

\begin{tabular}{lcccr}
\hline Culture collection site & $\begin{array}{c}\text { Latitude/ } \\
\text { longitude/ } \\
\text { elevation }(\mathrm{m})\end{array}$ & $\begin{array}{c}\text { Average annual } \\
\text { low temperature }\left({ }^{\circ} \mathrm{C}\right)\end{array}$ & $\begin{array}{c}\text { Low } \\
\text { range }\end{array}$ & $\begin{array}{c}\text { Average annual } \\
\text { high temperature }\left({ }^{\circ} \mathrm{C}\right)\end{array}$ \\
\hline $\begin{array}{l}\text { Riverside County: } \\
\text { Skunk Hollow }\end{array}$ & $33^{\circ} \mathrm{N}, 117^{\circ} \mathrm{W}, 407$ & 7.8 & $20.6-0.0$ & 32.0 \\
\hline $\begin{array}{l}\text { San Luis Obispo County: } \\
\text { Santa Margarita }\end{array}$ & $35^{\circ} 23.33^{\prime} \mathrm{N}, 120^{\circ} 36.69^{\prime} \mathrm{W}, 307$ & 5.0 & $11.1-6.1$ & 27.0 \\
\hline $\begin{array}{l}\text { Yolo County: } \\
\text { Davis }\end{array}$ & $38^{\circ} 33.43^{\prime} \mathrm{N}, 120^{\circ} 44.6^{\prime} \mathrm{W}, 14$ & 3.3 & $16.7 /-6.1$ & 22.8 \\
\hline $\begin{array}{l}\text { Lassen County: } \\
\text { Madeline Plains }\end{array}$ & $41^{\circ} 1.19^{\prime} \mathrm{N}, 120^{\circ} 29.09^{\prime} \mathrm{W}, 1618$ & -7.8 & $21.1 /-29.4$ & $35.6 / 2.8$ \\
\hline
\end{tabular}


tures at optimal Riverside County (origin) temperatures yielded no hatchings at all after being subjected to Lassen County temperatures. The Lassen County cultures subjected to Riverside County culture origin low temperature conditions (northernmost cultures at southern most culture temperatures) did not hatch, inhibited by the higher temperatures. However, when incubated at Lassen County low temperature conditions after Riverside County conditions, hatching occurred at an average of 19\% demonstrating that the higher temperatures did not affect the eggs of the northern most site.

Hatching variance was lowest in the control cultures (Tab. 2). Variance between replicates from site conditions adjacent to the control origin were different by an order of magnitude, while the treatment cultures furthest from the origin were not particularly different in their variance. In the Riverside County cultures, the origin cultures (Riverside conditions) had a variance of 0.67 . However, variance increased to 6.25 in culture 2 (San Luis Obispo conditions) and dropped slightly to 0.92 in culture 3 (Yolo conditions). Under San Luis Obispo County conditions, variance was lower in culture 2 ( 0.67 , origin conditions) and 4 (0.92, Lassen County conditions), while variance was higher in cultures 1 (8.92) and 3 (14.25). The Yolo County conditions variance was lowest in culture 3 (1.67, origin conditions) and 1 (1.67, Riverside County conditions), while cultures 2 (21.67) and 4 (30.0) had a far higher variance, nearly the opposite situation from the cultures run under San Luis Obispo County conditions. Under the Lassen County conditions, culture 4 (origin conditions) had a variance of 0.92 , while culture 2 had a variance of 2.25 , and culture 3 had a variance of 4.33 , again nearly the opposite situation from the cultures subjected to the Riverside County conditions.

Time to first clutch was shorter at higher temperatures (Tabs. 1 and 2). However body size and size of first clutch were smaller at higher than at lower temperatures. Time to first clutch variance was lowest in the origin cultures. In the Riverside County cultures, variance was lowest in cultures 1 (1.67) (origin) and 2 (7.85) (San Luis Obispo conditions), and differed by an order of magnitude from culture 3 (189.67) (Yolo conditions). Under the San Luis Obispo County conditions, variance was lower in cultures 2 (6.67) and 4 (11.58) by an order of magnitude than cultures 1 (124.92) and 3 (664.25). The Lassen County conditions yielded a similar result with cultures 4 (2.92, origin conditions) and 2 (4.92) having variance an order of magnitude lower than in culture 3 (94.33). Body length at first clutch and clutch size increased as temperature decreased. The relationship between first clutch size and body length within the cultures is presented in Fig. 1. There was no real variance in body length at first clutch (0.01) (Tab. 2). However, variance in first clutch size (Tab. 2) followed a somewhat similar pattern as was observed in hatching percentage and time to first clutch. Under Riverside County conditions variance was lowest in the origin conditions $(0.25)$, and increased across cultures with origins from south (2.92) to north (3.33). The San Luis Obispo conditions had cultures $2(0.33$, origin conditions) and $4(0.67)$ with variance an order of magnitude lower than cultures 1 (3.33) and 3 (3.33). Similarly, the Yolo County conditions had cultures $3(0.25$, origin conditions) and $1(0.92)$ with culture $2(0.92)$

Tab. 2. Averaged results from Branchinecta lindahli replicated cultures. All body lengths were measured from females bearing eggs.

\begin{tabular}{|c|c|c|c|c|c|c|c|}
\hline Site & $\begin{array}{l}\text { Replicate } \\
\text { conditions }\end{array}$ & $\begin{array}{c}\text { Temp. range }\left({ }^{\circ} \mathrm{C}\right) \\
\text { (low/high) }\end{array}$ & $\begin{array}{c}\% \text { hatch } \\
\text { (mean/var) }\end{array}$ & $\begin{array}{l}\text { Hours to first } \\
\text { clutch (mean/var) }\end{array}$ & $\begin{array}{l}\text { Body length }(\mathrm{mm}) \\
\text { at first clutch } \\
\text { (mean/var) }\end{array}$ & $\begin{array}{c}\text { First clutch } \\
\text { size (mean/var) }\end{array}$ & $\begin{array}{l}\text { Hours to } \\
\text { dry }\end{array}$ \\
\hline Riverside County & $\begin{array}{l}\text { Riverside } \\
\text { SLO } \\
\text { Yolo } \\
\text { Lassen }\end{array}$ & $\begin{array}{l}7.8 / 32.0 \\
5.0 / 27.0 \\
3.3 / 22.8 \\
-7.8 / 17.1\end{array}$ & $\begin{array}{c}18.0 / 0.67 \\
14.25 / 6.25 \\
9.75 / 0.92 \\
0\end{array}$ & $\begin{array}{c}70.5 / 1.67 \\
107.75 / 7.58 \\
215.5 / 189.67 \\
0\end{array}$ & $\begin{array}{c}9.25 / 0.01 \\
9.78 / 0.01 \\
12.23 / 0.01 \\
0\end{array}$ & $\begin{array}{c}11.25 / 0.25 \\
20.75 / 2.92 \\
31.0 / 3.33 \\
0\end{array}$ & $\begin{array}{l}225 \\
480 \\
630 \\
840\end{array}$ \\
\hline San Luis Obispo County & $\begin{array}{l}\text { Riverside } \\
\text { SLO } \\
\text { Yolo } \\
\text { Lassen }\end{array}$ & $\begin{array}{l}7.8 / 32.0 \\
5.0 / 27.0 \\
3.3 / 22.8 \\
-7.8 / 17.1\end{array}$ & $\begin{array}{c}18.75 / 8.92 \\
23.0 / 0.67 \\
16.75 / 14.25 \\
11.75 / 0.92\end{array}$ & $\begin{array}{c}129.75 / 124.92 \\
205 / 6.67 \\
372.25 / 664.25 \\
401.25 / 11.58\end{array}$ & $\begin{array}{c}7.73 / 0.01 \\
9.83 / 0.01 \\
11.25 / 0.01 \\
12.23 / 0.01\end{array}$ & $\begin{array}{c}10 / 3.33 \\
22.5 / 3.33 \\
40.0 / 3.33 \\
43 / 0.67\end{array}$ & $\begin{array}{l}240 \\
470 \\
640 \\
820\end{array}$ \\
\hline Yolo County & $\begin{array}{l}\text { Riverside } \\
\text { SLO } \\
\text { Yolo } \\
\text { Lassen }\end{array}$ & $\begin{array}{l}7.8 / 32.0 \\
5.0 / 27.0 \\
3.3 / 22.8 \\
-7.8 / 17.1\end{array}$ & $\begin{array}{c}17.5 / 1.67 \\
23.5 / 21.67 \\
29.5 / 1.67 \\
21.0 / 30.0\end{array}$ & $\begin{array}{c}158.5 / 9.67 \\
207.5 / 72.33 \\
333.25 / 4.92 \\
421.25 / 410.92\end{array}$ & $\begin{array}{c}7.13 / 0.01 \\
9.83 / 0.01 \\
10.8 / 0.01 \\
11.08 / 0.01\end{array}$ & $\begin{array}{c}3.25 / 0.92 \\
19.75 / 0.92 \\
25.25 / 0.25 \\
46.0 / 4.67\end{array}$ & $\begin{array}{l}225 \\
480 \\
630 \\
825\end{array}$ \\
\hline Lassen County & $\begin{array}{l}\text { Riverside } \\
\text { SLO } \\
\text { Yolo } \\
\text { Lassen }\end{array}$ & $\begin{array}{c}7.8 / 32.0 \\
5.0 / 27.0 \\
3.3 / 22.8 \\
-7.8 / 17.1\end{array}$ & $\begin{array}{c}0 \\
13.75 / 2.25 \\
14.75 / 4.33 \\
19.25 / 0.92\end{array}$ & $\begin{array}{c}0 \\
159.75 / 4.92 \\
361.5 / 94.33 \\
372.75 / 2.92\end{array}$ & $\begin{array}{c}0 \\
4.53 / 0.01 \\
9.08 / 0.01 \\
11.95 / 0.01\end{array}$ & $\begin{array}{c}0 \\
6.0 / 0.67 \\
24.75 / 35.58 \\
52.5 / 9.67\end{array}$ & $\begin{array}{l}230 \\
465 \\
620 \\
790\end{array}$ \\
\hline
\end{tabular}


and 4 (4.67). The Lassen County conditions had variance an order of magnitude lower in cultures 4 (9.67, origin conditions) and 2 (0.67) than in 3 (35.58).

Cultures collapsed more rapidly at higher temperatures, so the smallest body sizes at culture collapse are likely the result of shorter growth time (Tab. 2). The longer the culture was hydrated, the larger the final body size of the shrimp. Under natural conditions drying times would obviously be different depending upon the absorbance of the substrate, evapotranspiration rates, reflectiveness of the substrate, or recharge from the surrounding uplands. Therefore, no claim is made that collapse conditions are equal across cultures or reflective of natural conditions.

Only minor variation in the size of the individual eggs was observed, regardless of culture or hatching conditions. The mean egg diameter was $290.03 \mu \mathrm{m}$, with a range of: $282-295 \mu \mathrm{m}(\mathrm{SD}=3.66$; variance $=13.41)$. The range of variance between cultures and culture conditions was not statistically significant using a Student's $t$-test.

\section{DISCUSSION}

Anostraca are primarily limited to seasonally astatic wetlands which undergo varying dry periods. Persisting egg banks allow fairy shrimp to maintain populations in these somewhat unpredictable episodic habitats. Only a fraction of each egg clutch hatches with each inundation, leaving an egg bank behind to serve as a reservoir of eggs to maintain the species, in the event that one or more hatches die before reproducing, in a type of diversified bet hedging strategy (Philippi and Seger, 1989; Saiah and Perrin, 1990; Eriksen and Belk, 1999; Brendonck et al., 2000; Rogers, 2009). Hatching temperature is clearly an important aspect of adaptation to habitat local conditions,

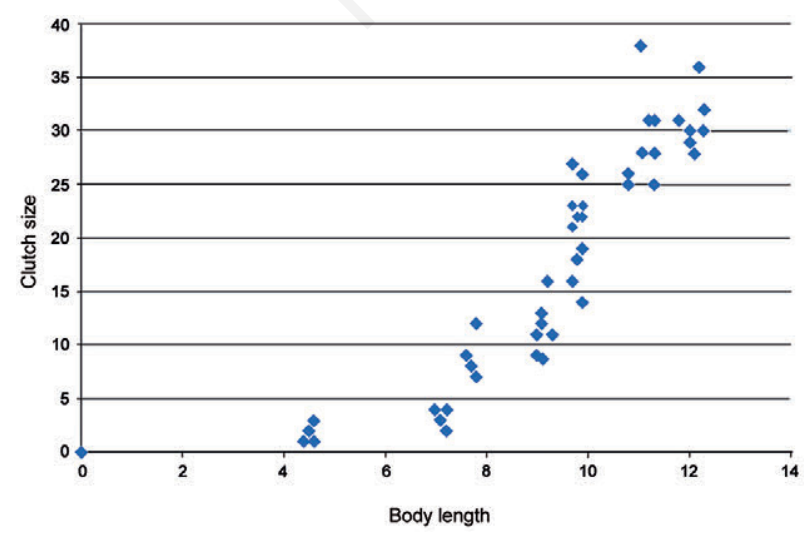

Fig. 1. Relationship between body length and first clutch size (total number of eggs) in Branchinecta lindahli cultures used in this study. Data may be truncated by the differential reduction in water volume in each culture (see discussion for further explanation). particularly in exploiting short hydroperiods for reproduction and this is supported by this study.

Branchinecta lindahli matured more rapidly, at a smaller size, and produced fewer eggs at higher temperatures; however, egg size was not affected. This intimates that $B$. lindahli will sacrifice body size to produce at least a few proper, high energy eggs in support of the egg bank during unfavourable conditions. Prophet (1963a, 1963b) observed the same phenomenon in B. packardi Pearse, 1912 (misidentified as B. lindahli, see Lynch, 1964 and specifically Belk in Donald, 1983) but did not recognize its significance. Prophet (1963a, 1963b) reared B. packardi to adult quickly at higher temperatures and had egg production within four days. However, as the culture water levels were maintained and kept from drying out, the animals continued to grow in size, producing successively larger clutches, increasing fecundity over time (Prophet, 1963a, 1963b; Brendonck et al., 1993). Additionally, the nutritional value of the food ingested by parent shrimp does not seem to affect egg viability or offspring sensitivity (Centeno et al., 1993). Therefore it seems that the function of the adult stage is to produce as many viable eggs as possible in whatever time is available.

It should be noted that body size is also affected by population density (Nagorskaya et al., 2004), such that higher densities of individuals per litre result in decreased growth rate, length, and weight. The results of this study associating body size with size of first clutch may be affected by the volume of the culture container, i.e., the space available may have circumscribed growth of larger individuals. Although culture densities were never more than 30 specimens per culture, the evaporating water may have circumscribed growth, as evidenced by the linear clumping of the data. Therefore, the data presented in Fig. 1 may be truncated by the differential reduction in water volume in each culture. Age to maturation period in populations from warmer climates (Riverside, San Luis Obispo) was significantly shorter than those from colder regions (Yolo, Lassen). The warmer climes mean shorter hydroperiods, as evaporation rates are higher, thus less time to generate gametes. In contrast, populations from more northerly latitudes delay hatching under snow and ice. When the melt comes, the hydroperiod is longer and there is more time to generate multiple clutches. Traditionally, this type of body size shift from smaller to larger as temperature decreases would be generally attributable to Bergmann's Rule (Bergmann, 1847; Van Voorhies, 1996), which states that within broadly distributed genera, colder environments tend to have larger bodied species and warmer environments tend have smaller bodied species. However, all cultures eventually progressed towards a similar ultimate body size and clutch size increased with each successive brood, regardless of temperature. No data were collected on the number of 
clutches per female. Branchinecta appear to continue to grow and reproduce during the hydroperiod allotted (Prophet, 1963a, 1963b; this study) in contrast to Branchinella kugenumaensis Ishikawa, 1895, which was reported to alternate growth with reproduction, spending energy on either one or the other, in an indeterminate growth strategy (Huang et al., 2010). The latitudinal variation in hatching temperature, time to first clutch and first clutch size demonstrates a pattern of adaptive significance. Theoretically, genetic variability should be higher in unstable environments than in homogeneous ones (Levins, 1968) since greater genetic variability is necessary for a population to persist and survive environmental vagaries. Since $B$. lindahli occupy habitats with dry summers, receiving virtually all precipitation during winter, cueing hatching on the lowest temperature is a predictive mechanism to increase the probability that hatching will occur at the earliest time in the wetland's limited hydroperiod. Lower temperatures would relate to longer hydroperiods (less evaporation and evapotranspiration), allowing the shrimp to reach a larger body size and thus a larger first clutch size before the habitat dries.

All the latitudinal cultures showed extensive overlap in the temperatures required to cue hatching. This variability would allow at least a certain percentage of dispersing eggs to survive different temperature conditions in new habitats, increasing potential survivorship, particularly in habitats a great distance from the natal habitat. Clegg et al. (2001) demonstrated that the anostracan Artemia franciscana Kellogg, 1906 from cool temperate northern California were able to adapt their hatching temperature within the first few years when cultured in open ponds in tropical Vietnam. The egg bank acts as a filter where different genotypes are favoured at different times and under different conditions (Templeton and Levin, 1979; Brendonck and Williams, 2000). The egg bank is also a storage mechanism, maintaining propagules during unfavourable years, so that there will be sufficient numbers in future good years to recharge the egg bank (Warner and Chesson, 1985). The high variability in habitat hydroperiod persistence would suggest that Anostraca would be on the r-strategist side of the r-k life history scale (Roff, 2001), wherein high fecundity would be coupled with low energy offspring. However, since mortality would be necessarily of a higher variability for juveniles than for adults (the possibility of numerous dryings or freezings killing off successive hatches prior to achieving reproductive age) then the basic r-strategy would reverse, in favour of a bet hedging strategy (Stearns, 1976, 1977; Philippi and Seger, 1989; Roff, 2001). Thus, anostracans may sacrifice body size in order to produce a few high energy eggs during less than optimal hydroperiod conditions.

Speculatively, an inbreeding anostracan population should logically have a simple, but structured gene pool with two or more monomorphic lineages, as demonstrated by the variance patterns in hatching, time to first clutch and first clutch size. These lineages would create heterozygotes when the lineages cross on years favourable to both lineages (Allard, 1970; Selander and Hudson, 1976; Brendonck, et al., 2000). Each monomorphic lineage within a pool should be adapted to a different condition in the pool. Each pool would have a high amount of genetic variability such that some fraction of the egg bank will hatch depending upon variation in local hatching temperature, or dispersing eggs reaching other habitats with similar or broader hydroperiod variations. The population is therefore adapted to the pool, but also maintains monomorphic lineages that can become specialists within the pool, with some lineages maturing rapidly (exploiting dry years with a short hydroperiod), while others mature more slowly (exploiting wet years with long hydroperiods). Hypothetically, lineages in a variable pool selected for dry years (maturing and producing eggs rapidly) would be more successful colonising habitat that consistently has shorter hydroperiods and higher temperatures. These lineages would be successful in smaller, shallower pools in warmer, drier climates, which would be unsuitable to longer hydroperiod lineages. Conversely, lineages from the same original pool selected for wet years (maturing and reproducing slowly) would have a higher success rate colonising deeper habitats in cooler, wetter climates.

Several studies have demonstrated that bisexual anostracan populations from shallower, smaller, habitats have less genetic variability than larger habitats, or have shown that genetic variability increases as habitat size increases (Abreu-Grobois, 1987; Pila and Beardmore, 1994; Gajardo et al., 1995; Brendonck, et al., 2000; Naihong et al., 2000). All these authors attributed these variations in heterozygosity to dispersal limitations rather than limitations of the habitat to support one or more lineages. Hildrew (1985) found short hydroperiod and long hydroperiod cohorts in the same pool for Streptocephalus vitreus (Brauer, 1877) and found variation in hatching requirements for eggs collected from the middle verses the edge of the pool. Zarattini et al. (2002) hatched Chirocephalus diaphanus Prévost, 1803 eggs, but reported that individual egg fractions hatched only after one, two or three hydrations, and each hatching group demonstrated a level of genetic distinction from the other two groups. Mura (2004) found variation in hatching response within individual pools depending upon whether the sediment was moist or dry prior to culture, and recognised that it may be the result of mixed genotypes within the egg bank.

Other studies have demonstrated that anostracan egg hatching is increased by favourable temperatures (Hall, 1961; Broch, 1965; Moore, 1967; Daborn, 1976; Modlin, 1982), suppressed by unfavourable temperatures (Hall, 1961; Nourisson, 1961; Broch, 1965; Moore, 1967; Belk, 
1973; Mossin, 1986; Saiah and Perrin, 1990; Belk and Nelson, 1995), and that variation in annual appearance of co-occurring species is attributed to variation in favourable temperatures between species (Moore, 1963; Prophet 1963c; Horne, 1967, 1971). Moore (1967) noted in Streptocephalus sealii Ryder, 1879 populations from a pool in Louisiana, USA, that the optimal hatching temperature was $21^{\circ} \mathrm{C}$, however hatching percentage increased if eggs were subjected to a temperature fluctuation from 19 to $23^{\circ} \mathrm{C}$ over a ten hour period every day. Eggs kept at a constant temperature had a lower hatching percentage. This demonstrates that the embryos cue in on fluctuating temperatures, which may indicate that the habitat will have passed temperatures too cold for growth and reproduction, as well as the chance that the habitat may not dry before maturity is reached.

The anostracan Eubranchipus grubii (Dybowski, 1860) populations produce winter and spring cohorts (Saiah and Perrin, 1990). The winter cohort hatches with the first autumnal rains and have a high mortality rate from the habitat freezing solid or drying completely dur- ing the winter months, whereas the spring cohort hatches after the spring thaw and dies when the habitat dries (Mossin, 1986). However, if the hydroperiod is uninterrupted, the winter cohort will have a longer time period to reproduce and will grow to a much larger body size (producing more eggs with each successive clutch) than the spring cohort (a difference in size of more than one third) (Saiah and Perrin, 1990). This size difference is a barrier to mating (Rogers, 2002).

Obviously there are limits to the phenotypic plasticity of hatching temperature response, as the southernmost (Riverside County) culture died when subjected to the freezing conditions of the northernmost (Lassen County) origin. Conversely, the northernmost culture did not recognise any hatching cues at the higher temperature of the southernmost origin. However, when subjected to conditions from its origin, hatching did occur, but at a lower fraction than for the same cultures that were only given origin conditions. This suggests that the Riverside County conditions either caused some mortality or provided hatching inhibition cues (Belk, 1973; Belk and Nelson, 1995).

Tab. 3. Shortest time to first observed female with clutch for various Branchinecta species. All field collected data. Days to first clutch defined as from time habitat first inundated until first females with fertilized eggs appeared.

\begin{tabular}{|c|c|c|c|c|c|}
\hline Species & Origin & $\begin{array}{l}\text { First } \\
\text { clutch } \\
\text { (days) }\end{array}$ & $\begin{array}{l}\text { Body } \\
\text { length } \\
(\mathrm{mm})\end{array}$ & $\begin{array}{l}\text { Clutch } \\
\text { size }\end{array}$ & N/variance \\
\hline B. coloradensis & $\begin{array}{l}\text { USA: California: Lassen Co: Poison Lake } \\
\text { April } 1990\end{array}$ & 21 & 9.3 & 43 & $8 / 1.67$ \\
\hline B. dissimilis & $\begin{array}{l}\text { USA: California: Modoc Co: Clear lake Road } \\
\text { March } 1998\end{array}$ & 27 & 9.4 & 31 & $3 / 0.67$ \\
\hline B. ferrolimneta & $\begin{array}{l}\text { BRASIL: Minas Gerias: Nova Lima } \\
\text { October } 2002\end{array}$ & 11 & 7.1 & 36 & $1 / 0$ \\
\hline B. gigas & $\begin{array}{l}\text { USA: California: Siskiyou Co: nr Indian Tom Lake, } \\
\text { March } 2006\end{array}$ & 31 & 72.3 & 28 & $4 / 1.67$ \\
\hline B. hiberna & $\begin{array}{l}\text { USA: California: Modoc Co: Clear Lake Road } \\
\text { March } 1998\end{array}$ & 17 & 8.9 & 37 & $3 / 0.92$ \\
\hline \multirow[t]{2}{*}{ B. lynchi } & $\begin{array}{l}\text { USA: California: Shasta Co: Palo Cedro } \\
\text { June } 1993\end{array}$ & 6 & 4.4 & 2 & $5 / 0$ \\
\hline & $\begin{array}{l}\text { USA: California: Tehama Co: Spring Branch Road, } \\
\text { January } 1988\end{array}$ & 12 & 7.1 & 24 & $4 / 8.92$ \\
\hline \multirow[t]{3}{*}{ B. mackini } & $\begin{array}{l}\text { USA: California: Siskiyou Co: nr Indian Tom Lake, } \\
\text { March } 2006\end{array}$ & 19 & 14.2 & 41 & $4 / 1.67$ \\
\hline & $\begin{array}{l}\text { USA: California: Modoc Co: Middle Alkali Lake, } \\
1993\end{array}$ & 16 & 16.4 & 48 & $3 / 2.92$ \\
\hline & $\begin{array}{l}\text { USA: Nevada: Humbolt Co: nr Golconda } \\
\text { May } 2007\end{array}$ & 14 & 8.1 & 26 & $8 / 0.92$ \\
\hline \multirow[t]{2}{*}{ B. sandiegonensis } & $\begin{array}{l}\text { USA: California: San Diego Co: Otay Mesa } \\
\text { November } 2001\end{array}$ & 3 & 4.9 & 2 & $7 / 0$ \\
\hline & $\begin{array}{l}\text { USA: California: San Diego Co: Otay Mesa } \\
\text { Culture }\end{array}$ & 7 & 8.4 & 19 & $5 / 0.33$ \\
\hline
\end{tabular}


Different lineages sharing a single habitat have been observed in the genus Branchinecta; however these lineages were different species (Eriksen and Belk, 1999; Rogers and Fugate, 2001; Rogers et al., 2006). Tab. 3 presents qualitative field and culture data of time to first observed clutch in different populations of Branchinecta species. The species $B$. hiberna (Rogers and Fugate, 2001) and $B$. dissimilis Lynch, 1972 were observed in the same pool in 1998 (Tab. 3; Rogers and Fugate, 2001). These two species co-occur, and are potential competitors; however $B$. hiberna rapidly grows to maturity in about a third less time than B. disimilis. Branchinecta hiberna was also reported as cöoccurring with $B$. lindahli and $B$. coloradensis Packard, 1874 in Idaho (in separate habitats), with the same rapid development and maturing faster than the other two species (Rogers et al., 2006). Two of the $B$. mackini Dexter, 1956 populations listed in Tab. 3 were co-occurring with the predatory Branchinecta gigas Lynch, 1937, which prey primarily on upon B. mackini. The habitat with the $B$. mackini population from Nevada reported in Tab. 3 does not support $B$. gigas. The two populations that were under predatory pressure grew quickly, faster than the B. gigas, but with smaller clutch sizes than would be expected for their size. It is possible that these B. mackini populations spend more energy on growth than gametes, if increased size impedes predation by the congener. The Nevada population began reproduction earlier and at a smaller size than the other two populations. Later collections from the same year, nearing desiccation, yielded B. mackini with adult lengths of $34.4 \mathrm{~mm}$ and 32.9 $\mathrm{mm}$ from the two California sites, and $14.1 \mathrm{~mm}$ from the Nevada site. Similar average size was observed in a pool in Idaho, where the giant predator B. raptor Rogers et al. 2006, occurs with B. mackini (33.1 mm). Branchinecta mackini is not only longer in habitats occupied by predatory congeners, it is also more robust: volumetric displacements $\left(5 \mathrm{~mL}\right.$ deionised tap water at $\left.20^{\circ} \mathrm{C}\right)$ from the Middle Alkali Lake site averaged $2.55 \mathrm{~mL}$, whereas the Nevada population average was $0.05 \mathrm{~mL}$.

The results from this data set also demonstrate that during higher temperatures, these species can reproduce and complete their lifecycle in less than a fortnight (note the data in Tab. 3 for B. lynchi Eng et al., 1990, and B. sandiegonensis Fugate, 1993). These two species are both afforded protection under the US Endangered Species Act (Federal Register, 1994, 1997). Current US Fish and Wildlife Service protocols (US Department of the Interior, 1996) require that where surveys for these and other listed species are conducted, the surveys begin two weeks after the habitats have held $2.5 \mathrm{~cm}$ of water for two weeks. However, since these species can complete their lifecycle in as little as three or six days at higher temperatures, it is possible that occurrences of these species have been missed under the current survey protocols.

\section{CONCLUSIONS}

Branchinecta lindahli matures and reproduces more quickly at higher temperatures, but does so at a smaller body and clutch size, still producing normal sized eggs (i.e., the eggs are not reduced in size as is the adult). At lower temperatures $B$. lindahli matures more slowly, at a larger body size, but produces a far larger clutch. Phenotypic responses in hatching temperature and growth rate may cause genetic segregation within an anostracan population in a given habitat, selecting one cohort for dry years and one cohort for wet years. Cohorts selected for drier years can exploit habitats that have smaller hydroperiods even in wet years. This may lead to population specialisation and speciation by adapting to more extreme habitats or to specific conditions in other habitats.

\section{ACKNOWLEDGMENTS}

I am grateful to Don Huggins, Barbra Hayford, Brian O'Neil and James Thorp for helpful discussions. I want to thank Hazel Rogers and Barbra Hayford for commenting on early drafts. I thank Martin Thoms, Ed Martinko, and Brian Timms for their comments and guidance. I am grateful for the comments provided by the two anonymous reviewers and Federico Marrone. The reviews were detail oriented and helpful.

\section{REFERENCES}

Abreu-Grobois A, 1987. Review of the genetics of Artemia, p. 61-99. In: P.D. Sorgeloos, A. Bengston, W. Decleir and E. Jaspers (eds.) Artemia research and its applications, 1. Morphology, genetics strain characterization, and toxicology. Universa Press.

Allard RW, 1970. Population structure and sampling methods, p. 97-107. In: O.H. Frankel and E. Bennett (eds.) Genetic resources in plants - their exploration and conservation. Davis.

Belk D, 1973. Suggestion of a timing mechanism inhibiting hatching after the first day of wetting in Branchinecta lindahli Packard eggs. Am. Zool. 13:1339.

Belk D, 1975. Key to the Anostraca (fairy shrimps) of North America. Southwest. Nat. 20:91-103.

Belk D, 1977a. Evolution of egg size strategies in fairy shrimps. Southwest. Nat. 22:99-105.

Belk D, 1977b. Zoogeography of the arizona fairy shrimps, (Crustacea: Anostraca). Arizona Acad. Sci. 12:70-78.

Belk D, 1983. New fairy shrimp distribution records among collections at the California Academy of Sciences. Southwest. Nat. 28:380-381.

Belk D, Brtek J, 1995. Checklist of the Anostraca. Hydrobiologia 298:315-353.

Belk D, Cole G, 1975. Adaptational biology of desert temporary-pond inhabitants, p. 207-206. In: N.F. Hadley (ed.) Environmental physiology of desert organisms. Dowden, Hutchinson and Ross, Inc.

Belk D, Nelson T, 1995. Observations on the effects of incubation at inhibitory temperature on subsequent hatching of anostracan cysts. Hydrobiologia 298:179-181. 
Bergmann C, 1847. [Über die Verhältnisse der Wärmeökonomie der Theire zu iher Grösse].[Article in German]. Göttinger Studien 3:595-708.

Brendonck L, 1996. Diapause, quiescence, hatching requirements: what can we learn from large freshwater branchiopods (Crustacea: Branchiopoda: Anostraca, Notostraca, Conchostraca). Hydrobiologia 320:85-97.

Brendonck L, Centeno DM, Persoone G, 1993. Fecundity and resting egg characteristics of some subtropical fairy shrimp and clam shrimp species (Crustacea: Branchiopoda), reared under laboratory conditions. Arch. Hydrobiol. 126:445-459.

Brendonck L, De Meester L, Riddoch BJ, 2000. Regional structuring of genetic variation in short lived rock pool populations of Branchipodopsis wolfi (Crustacea: Anostraca). Oecologica 123:506-515.

Brendonck L, Williams WD, 2000. Biodiversity in wetlands of dry regions (drylands). P- 181-194. In: B. Gopal, W.J. Junk and J.A. Davis (eds.) Biodiversity in wetlands: assessment, function and conservation, 1. Backhuys Publishers.

Broch ES, 1965. Mechanism of adaptation of the fairy shrimp Chirocephalopsis bundyi Forbes to the temporary pond. Cornell University Agricultural Experimental Station Memoir 392:1-48.

Clegg JS, Van Hoa N, Sorgeloos, 2001. Thermal tolerance and heat shock proteins in encysted embryos of Artemia from widely different thermal habitats. Hydrobiologia 466:21-229.

Centeno MDF, Brendonck L, Persoone G, 1993. Influence of production, processing and storage conditions of resting eggs of Streptocephalus proboscideus (Crustacea: Branchiopoda: Anostraca) on the sensitivity of larvae to selected reference toxicants. B. Environ. Contam. Tox. 51:927-934.

Daborn GR, 1976. The lifecycle of Eubranchipus bundyi (Forbes) (Crustacea: Anostraca) in a temporary vernal pond of Alberta. Can. J. Zool. 54:193-201.

Donald DB, 1983. Erratic occurrences of anostracans in a temporary pond: colonization and extinction or adaptation to variations in annual weather? Can. J. Zool. 61:1492-1498.

Eng L, Belk D, Eriksen C, 1990. Californian Anostraca: distribution, habitat, and status. J. Crustacean Biol. 10:47-277.

Eriksen CH, Belk D, 1999. The fairy shrimps of California's pools, puddles, and playas. Mad River Press: $196 \mathrm{pp}$.

Federal Register, 1994. Fish and wildlife service, Department of the Interior. Endangered and threatened wildlife and plants; Determination of endangered status and withdrawal of proposal to give endangered status; Final rule and proposed rule; Determination of endangered status for the conservancy fairy shrimp, Longhorn Fairy shrimp, and the vernal pool tadpole shrimp; and threatened status for the vernal pool fairy shrimp. Federal Register 59:48153-48185.

Federal Register, 1997. Fish and wildlife service, Department of the Interior. Endangered and threatened wildlife and plants; Determination of endangered status for the San Diego fairy shrimp. Federal Register 62:4925-4939.

Gajardo GM, Conceicao M, Weber L, Beardmore JA, 1995. Genetic variability and interpopulational differentiation of Artemia strains from South America. Hydrobiology 302:21-29.

Gonzales RJ, Drazen J, Hathaway J, Bauer B, Simovich M, 1996. Physiological correlates of water chemistry in fairy shrimps (Anostraca) from southern California. J. Crustacean Biol. 16:315-322.
Hartland-Rowe R, 1965. The Anostraca and Notostraca of Canada with some new distribution records. Can. Nat. 79:185-189.

Hall RE, 1959. Delayed development of eggs of Chirocephalus diaphanous Prévost. Hydrobiologia 13:160-169.

Hall RE, 1961. On some aspects of the natural occurrence of Chirocephalus diaphanus Prévost. Hydrobiologia 17:205-217.

Hildrew AG, 1985. A quantitative study of the life history of a fairy shrimp (Branchiopoda: Anostraca) in relation to the temporary nature of its habitat, a Kenyan rainpool. J. Anim. Ecol. 54: 99-110.

Horne FR, 1967. Effects of physical-chemical factors on the distribution and occurrence of some southeastern Wyoming phyllopods. Ecology 48:472-477.

Horne FR, 1971. Some effects of temperature and oxygen concentration on phyllopod ecology. Ecology 52:343-347.

Huang SL, Wang CC, Huang WP, Chou LS, 2010. Indeterminate growth of the fairy shrimp, Branchinella (Branchinellites) kugenumaensis (Branchiopoda; Anostraca) in an unpredictable ephemeral pool. J. Crustacean Biol. 30:366-372.

Levins R, 1968. Evolution in changing environments. Princeton University Press: 132 pp.

Lynch JE, 1964. Packard's and Pearse's species of Branchinecta: analysis of a nomenclatural involvement. Am. Mid. Nat. 71:466-488.

Maeda-Martinez A, Obregon-Barboza H, Garcia-Velazco H, Prieto-Salazar MA, 2002. [Branchiopoda: Anostraca, p. 305322]. In: J.L. Bousquets and J.J. Morrone (eds.) [Biodiversidad, Taxonomia y Biogeografia de Artropodos de Mexico: hacia una sintesis de su conocimiento, III].[Book in Spanish]. Universidad Nacional Autonoma de Mexico.

Modlin RF, 1982. A comparison of two Eubranchipus species (Crustacea: Anostraca). Am. Mid. Nat. 107:107-113.

Moore WG, 1963. Some interspecies relationships in Anostraca populations of certain Louisiana ponds. Ecology 44:131-139.

Moore WG, 1967. Factors affecting egg-hatching in Streptocephalus seali (sic) (Branchiopoda, Crustacea), p. 724-735. Proceedings of the Symposium on Crustacea, Part II, Marine Biological association of India, Ernakulam.

Mossin J, 1986. Physiochemical factors inducing embryonic development and spring hatching of the European fairy shrimp Siphonophanes grubei (Dybowski) (Crustacea: Anostraca). J. Crustacean Biol. 64:693-704.

Mura G, 2004. Structure and functioning of the "egg bank" of a fairy shrimp in a temporary pool: Chirocephalus ruffoi from Pollino National Park (Southern Italy) as a case study. Int. Rev. Hydrobiol. 89:35-50.

Nagorskaya L, Brecciaroli B, Mura G, 2004. The effect of rearing density on body size and weight increase in Streptocephalus torvicornis (Anostraca). Crustaceana 77:231-243.

Naihong X, Audenaert E, Vanoverbeke J, Brendonck L, Sorgeloos P, De Meester L, 2000. Low among population genetic differentiation in Chinese bisexual Artemia populations. Heredity 84:238-243.

Nourisson M, 1961. [Influence d'un thermopériodisme journalier sur le développement des oeufs non asséches de Chirocephalus stagnalis Shaw].[Article in French]. C. R. Acad. Sci. 253:1870-1872.

Philippi T, Seger J, 1989. Hedging one's evolutionary bets, revisited. Trends Ecol. Evol. 4:41-44. 
Pila JS, Beardmore JA, 1994. Genetic and morphometric differentiation in Old World bisexual species of Artemia (the brine shrimp). Heredity 73:47-56.

Prophet CW, 1963a. Some factors influencing the hatching of anostracan eggs. Trans. Kansas Acad. Sci. 68:150-159.

Prophet CW 1963b. Egg production by laboratory cultured Anostraca. Southwest. Nat. 8:32-37.

Prophet CW, 1963c. Physical-chemical characteristics of habitats and seasonal occurrence of some Anostraca in Oklahoma and Kansas. Ecology 44:798-801.

Roff DA, 2001. Life history evolution. Sinauer Associates, Inc.: $465 \mathrm{pp}$.

Rogers DC, 2002. The amplexial morphology of selected Anostraca. Hydrobiologia 486:1-18.

Rogers DC, 2009. Branchiopoda (Anostraca, Notostraca, Laevicaudata, Spinicaudata, Cyclestherida), p. 242-249. In: G.F. Likens (ed.) Encyclopaedia of inland waters. 2. Elsevier.

Rogers DC, Fugate M, 2001. Branchinecta hiberna, a new species of fairy shrimp (Crustacea: Anostraca) from western North America. West. N. Am. Nat. 61:11-18.

Rogers DC, Quinney D, Weaver J, Olesen J, 2006. A new giant species of predatory fairy shrimp from Idaho (Branchiopoda: Anostraca). J. Crustacean Biol. 26:1-16.

Saiah H, Perrin N, 1990. Autumnal vs spring hatching in the fairy shrimp Siphonophanes grubii (Dybowski) (Crustacea, Anostraca): diversified bet-hedging strategy? Funct. Ecol. 4:769-775.

Simovich MA, Fugate M, 1992. Branchiopod diversity in San
Diego County, California, USA. T. W. Sec. Wil. 28:6-14.

Selander RK, Hudson RO, 1976. Animal population structure under close inbreeding: the land snail Rumina in southern France. Am. Nat. 110:695-718.

Stearns SC, 1976. Life-history tactics: a review of the ideas. Q. Rev. Biol. 51:3-47.

Stearns SC, 1977. The evolution of life-history traits: a critique of the theory and a review ofthe data. Annu. Rev. Ecol. Syst. 8:145-171.

Templeton AR, Levin DA, 1979. Evolutionary consequences of seed pools. Am. Nat. 114:232-249.

US Department of the Interior, 1996. Interim survey guidelines to permittees for recovery permits under the endangered species act for the listed vernal pool branchiopods. Available from: http://www.fws.gov/pacific/ecoservices/endangered/recovery/documents/VernalPoolBranchiopods1996Protocol.pdf

Van Voorhies WA, 1996. Bergmann size clines: a simple explanation for their occurrence in ectotherms. Evolution 50:1259-1264.

Warner RR, Chesson PL, 1985. Coexistance mediated by recruitment fluctuations: a field guide to the storage effect. Am. Nat. 125:769-787.

Zarattini P, Rossi V, Mantovani B, Mura G, 2002. Preliminary study in the use of RAPD markers in detecting genetic differences in hatching patterns of Chirocephalus diaphanus Prévost, 1803 (Crustacea: Anostraca). Hydrobiologia 486:315-323. 